\title{
Morphogenic and structural characteristics of guinea grass pastures submitted to three frequencies and two defoliation severities
}

\author{
Rodrigo Amorim Barbosa ${ }^{1}$, Domicio do Nascimento Júnior ${ }^{2}$, Hélio Henrique Vilela ${ }^{2}$, Sila \\ Carneiro da Silva ${ }^{3}$, Valéria Pacheco Batista Euclides ${ }^{1}$, André Fischer Sbrissia ${ }^{4}$, Braulio Maia \\ de Lana Sousa ${ }^{2}$
}

\footnotetext{
1 EMBRAPA CNPGC - Rodovia BR 262, km 4, Caixa Postal 154, 79002-970, Campo Grande/MS

2 Universidade Federal de Viçosa, Departamento de Zootecnia, Viçosa/MG.

3 Universidade de São Paulo, Escola Superior de Agricultura "Luiz de Queiroz", Departamento de Zootecnia, Piracicaba/SP.

${ }^{4}$ Universidade do Estado de Santa Catarina, Departamento de Produção Animal e Alimentos, Lages/SC.
}

\begin{abstract}
It was evaluated the morphogenic and structural characteristics of guinea grass under rotational at three grazing intervals and two defoliation intensities. Grazing intervals corresponded to the time needed by the forage canopy to reach 90 , 95 or $100 \%$ of incident light interception during regrowth and they were evaluated combined to two defoliation severities (post-grazing conditions, 25 and $50 \mathrm{~cm}$ of height), being allocated to experimental units according to a complete randomized design, with three replicates and $3 \times 2$ factorial arrangement. The experiment was conducted from July 2003 to May 2004. For evaluation of morphogenetic and structural characteristics, ten tillers per experimental unit were selected. Morphogenetic and structural characteristics were strongly influenced by seasons of the year inasmuch as leaf elongation rate increased 3.5 fold from winter to summer. In addition to year season effect, there was also an effect of defoliation frequencies on tiller population density, which was greater in the defoliation period corresponding to $90 \%$ of light interception, especially if evaluated in relation to the interval corresponding to $100 \%$ of light interception. Defoliation frequency is determinant in expression of phenotypic plasticit, acting on the control of stem elongation.
\end{abstract}

Key Words: canopy height, grazing management, light interception, Panicum maximum

\section{Características morfogênicas e estruturais de pastos de capim-tanzânia submetidos a três frequências e duas severidades de desfolhação}

RESUMO - Foram avaliadas as características morfogênicas e estruturais do capim-tanzânia sob lotação rotativa em três intervalos de pastejo e duas severidades de desfolhação. Os intervalos de pastejo corresponderam aos tempos necessários para que o dossel forrageiro atingisse 90, 95 ou 100\% de interceptação da luz incidente, durante a rebrotação e foram avaliados em combinação a duas severidades de desfolhação (condições pós-pastejo, 25 e $50 \mathrm{~cm}$ de altura), sendo alocados às unidades experimentais segundo um delineamento de blocos completos casualizados, com três repetições e arranjo fatorial $3 \times 2$. O experimento foi realizado de julho de 2003 a maio de 2004. Para avaliação das características morfogênicas e estruturais, foram selecionados dez perfilhos por unidade experimental. As características morfogênicas e estruturais foram fortemente influenciadas pelas épocas do ano, uma vez que a taxa de alongamento de folhas aumentou 3,5 vezes do inverno para o verão Além do efeito da época do ano, também houve efeito das frequências de desfolhação sobre a densidade populacional de perfilhos, que foi maior no intervalo de desfolhação correspondente a $90 \%$ da interceptação luminosa, principalmente se avaliado em relação ao intervalo correspondente a $100 \%$ da interceptação luminosa. A frequência de desfolhação é determinante na expressão da plasticidade fenotípica, principalmente por influenciar na densidade populacional de perfilhos, atuando no controle do alongamento dos colmos.

Palavras-chave: altura do dossel, interceptação de luz, manejo do pastejo, Panicum maximum

\section{Introduction}

Morphogenesis can be expressed by the tissue appearance rate, the expansion of new organs and senescence (Chapman \& Lemaire, 1993). In a sward in the vegetative stage, morphogenesis can be described by the three basic characteristics: appearance, elongation and the lifespan of leaves. These characteristics are determined genetically, but they can be influenced by environmental factors, such as temperature (Duru \& Ducrocq, 2000), light intensity (Van Esbroeck et al., 1989), water availability (Caetano \& Dias-Filho, 2008), nutrients(Garcez Neto etal., 2002) 
and grazing effects (Barbosa et al., 2002; Difante et al., 2009). These factors define the rates and duration of the processes (organogenesis).

Another important morphogenic component is stem elongation (Sbrissia \& Da Silva, 2001). This characteristic increases forage yield (Santos et al., 2004) and interferes significantly with the canopy structure. Furthermore, it impedes and endangers grazing efficiency because of the alterations in the leaf blade to stem ratio. This ratio is directly related to the performance of the grazing animals (Euclides et al., 2000; Difante et al., 2008).

A database consisting of the morphogenic characteristics that determine the pasture structure is necessary to identify the conditions that maximize the efficiency of yield and harvest. This database, combined with the evidence of the effects of the canopy structure on forage intake and animal performance, lead to the development of management strategies based on the pasture conditions. The management goals have been defined by the canopy height (Hodgson, 1990) or forage mass (Matthews et al., 1999).

The objective of this study was to evaluate the morphogenic and structural characteristics of Tanzania grass (Panicum maximum Jacq. cv. Tanzânia) under rotational stocking.

\section{Material and Methods}

The experiment was conducted in Embrapa Gado de Corte - CNPGC, in Campo Grande/MS. The geographic coordinates of this site are $20^{\circ} 27^{\prime} \mathrm{S}$ and $54^{\circ} 37^{\prime} \mathrm{W}$, and the altitude is $530 \mathrm{~m}$. According to the Köppen classification, the climate is tropical wet savannah type, subtype Aw. The area is characterized by the irregular annual distribution of rain, with a well-defined dry period during the colder months and a rainy period during the summer months (Figures 1 and 2).

The climate data were recorded at the Embrapa Gado de Corte (Beef Cattle Embrapa) Weather Station, approximately $800 \mathrm{~m}$ from the experiment site.

Sowing was performed by using $2 \mathrm{~kg} / \mathrm{ha}$ of viable pure seeds in January 1995. The seeds were incorporated into the soil by light harrowing, followed by light compaction by rolling tires. The area has been kept under grazing since August 1995. The experiment lasted a total of 434 days (May $8^{\text {th }} 2003$ to May $15^{\text {th }}$ 2004), with data collection from July $11^{\text {th }} 2003$ to May $15^{\text {th }} 2004$, totaling 309 days. The period from May $8^{\text {th }} 2003$ to July $10^{\text {th }} 2003$ was used to control invading plants, to collect soil samples for analysis and to standardize grazing of the experimental area.

The soil in the experimental area was classified as Rhodic Ferralsol (FAO, 2006), and the results of the fertility analysis are the following: base saturation $(\mathrm{V})=44 \%, \mathrm{P}=$ $4.73 \mathrm{mg} / \mathrm{dm}^{3}$ (Mehlich1); $\mathrm{K}=122.1 \mathrm{mgdm}^{-3} ; \mathrm{Ca}=1.74 \mathrm{cmolc} / \mathrm{dm}^{3}$; $\mathrm{Mg}=1.38 \mathrm{cmolc} / \mathrm{dm}^{3} ; \mathrm{pH}\left(\mathrm{CaCl}_{2}\right)=5.0$; cation exchange capacity $=7.93 \mathrm{cmolc} / \mathrm{dm}^{3}$. Based on these results, the standardization and fertilization of the area was performed. A total of 2,500 kg/ha of dolomitic limestone (PRNT 75\%) and $300 \mathrm{~kg} / \mathrm{ha}$ of 0-20-20 formulation (NPK) were applied. A total of $200 \mathrm{~kg} / \mathrm{ha}$ of nitrogen as urea was also added into the paddocks.

All of the areas with $90 \%$ and $95 \%$ light interception (LI) received four applications of $50 \mathrm{~kg} / \mathrm{ha} \mathrm{N}$. The area with $100 \% \mathrm{LI}$ and $50 \mathrm{~cm}$ of residue received one application of $50 \mathrm{~kg} / \mathrm{ha} \mathrm{N}$, followed by two applications of $70 \mathrm{~kg} / \mathrm{ha} \mathrm{N}$ and a final application of $10 \mathrm{~kg} / \mathrm{ha} \mathrm{N}$. The area with $100 \% \mathrm{LI}$ and $25 \mathrm{~cm}$ of residue received one application of $50 \mathrm{~kg} / \mathrm{ha} \mathrm{N}$ followed by one application of $70 \mathrm{~kg} / \mathrm{ha} \mathrm{N}$ and a final application of $80 \mathrm{~kg} / \mathrm{ha} \mathrm{N}$.

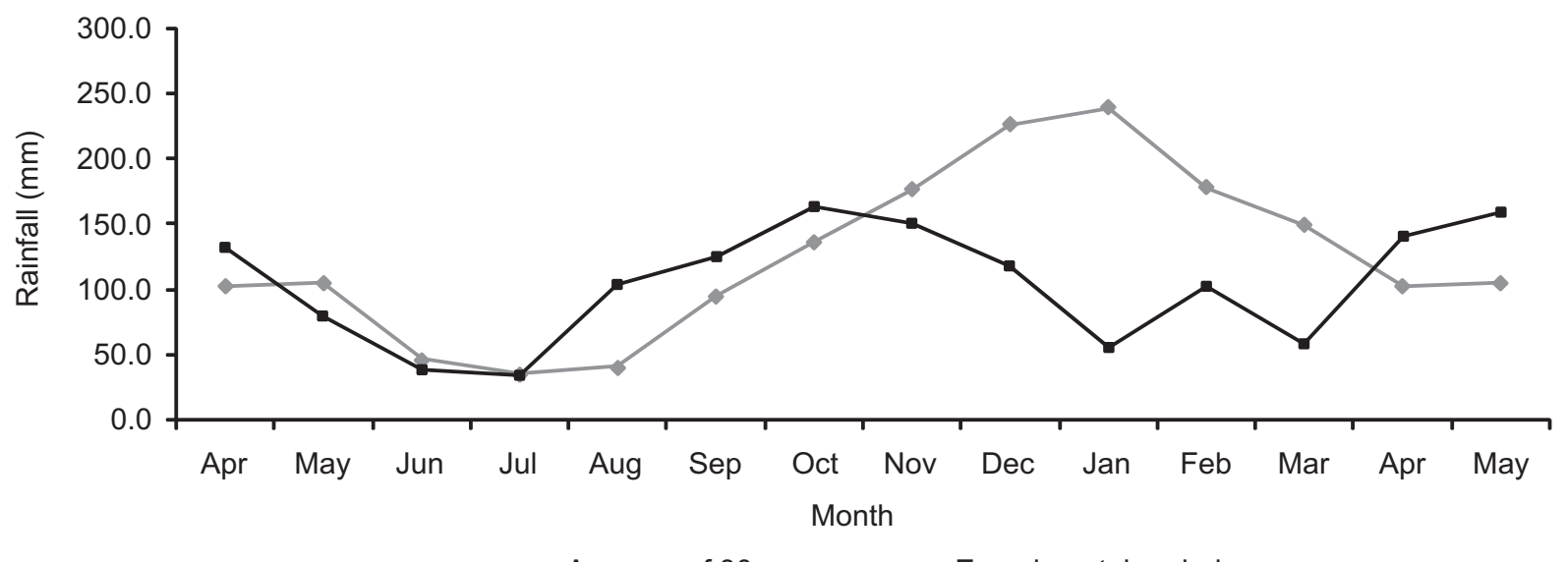

Average of 30 years

Experimental period

Figure 1 - Distribution of rainfall during the experimental period and in the last 30 years. 


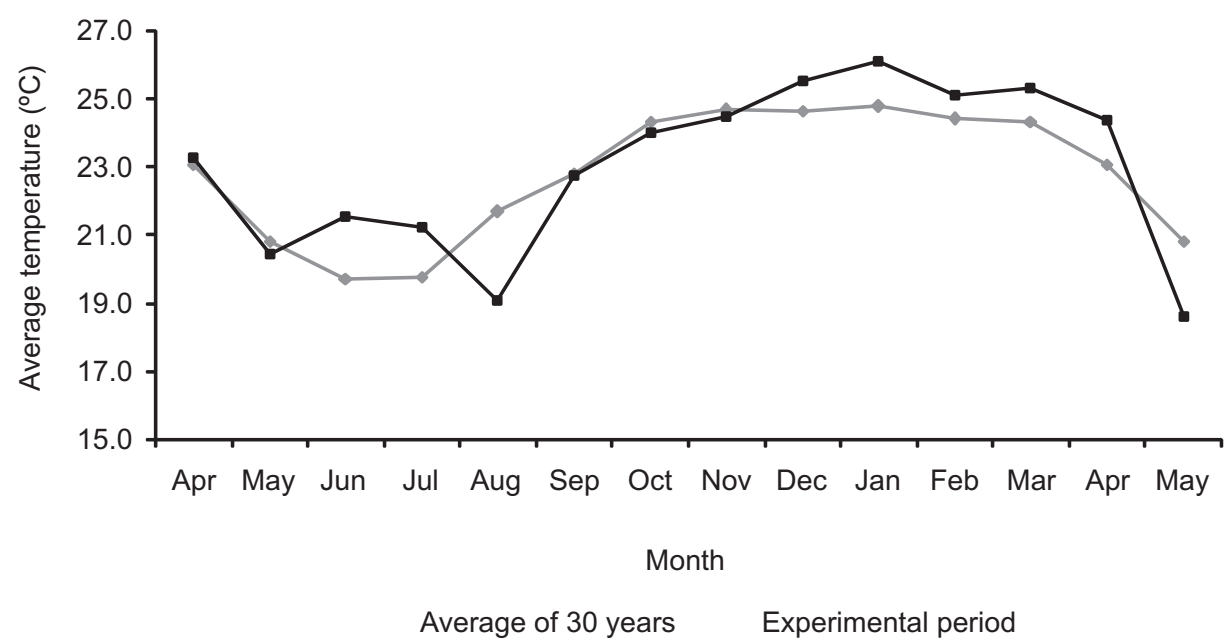

Figure 2 - Average temperatures $\left({ }^{\circ} \mathrm{C}\right)$ during the experimental period and in the last 30 years.

The experimental plot was subdivided into three blocks of 1.5 hectares with six paddocks (experimental units) of 0.25 hectare. Nelore steers at 18 months of age and with an average weight of $310 \mathrm{~kg}$ were used for the grazings. When the animals were not needed in the study, they grazed in an area consisting of 3.0 ha of Mombaça grass, 3.0 ha of Massai grass and 1.5 ha of Tanzania grass.

It was used a completely randomized $3 \times 2$ factorial block design with three intervals and two grazing severities, with three replicates, yielding a total of 18 experimental units. The grazing intervals corresponded to the time period necessary for the forage canopy to reach $90 \%, 95 \%$ or $100 \%$ of interception of incident light during regrowth. The grazing intensities corresponded to the residue heights of 25 and $50 \mathrm{~cm}$.

The monitoring of light interception by the canopy was performed under the post-grazing condition ( 25 and $50 \mathrm{~cm}$ ) and at variable time intervals during regrowth for each season. In the winter, the evaluation interval was 15 days for the $90 \%$ and $95 \%$ paddocks of LI and 20 days for the $100 \%$ paddocks of LI. During the rest of the year, the interval was reduced to 7 days in the treatments of $90 \%$ and $95 \%$ LI and 10 days for the treatments of $100 \%$ LI. When the levels of light interception were close to the pre-grazing levels, the monitoring frequency was increased with evaluations every three days. In the evaluations, the canopy was analyzed with an AccuPAR Linear PAR/LAI ceptometer, Model PAR 80(Decagon Devices, EUA). Readings were collected at six sampling points per paddock (Carnevalli et al., 2006). At each point, three readings above the forage canopy and three readings close to the ground were performed. Each reading was the mean of five instantaneous readings.
In the early part of each regrowth period, ten tillers were randomly tagged for evaluation of the morphogenic and structural characteristics of the canopy during the rest period of the pastures. The tillers were identified with plastic rings, and a pole with numbered tags was fixed beside each tiller for better visualization in the field. The evaluations were performed every 15 days in the winter and every 7 days during the other seasons. The length of the leaf blades and the height of the ligule of the last expanded leaf were measured during these evaluations. Furthermore, the number of new leaves appearing on each of the tillers at each evaluation was recorded. These data were used to calculate the following variables.

1) Leaf appearance rate (LAR), which is the number of leaves appearing per tiller, divided by the number of days of the evaluation period (leaves/tiller.day)

2) Phyllochron (PHY), which is the opposite of leaf appearance rate (days/leaf.tiller)

3) Leaf elongation rate (LER), which is the summation of all elongation of the leaf per tiller divided by the number of days of the evaluation period (cm/tiller.day)

4) Final length of the leaf blade (FLLB), which is the average length of all the leaves of the tiller, measured from the leaf apex to the ligule $(\mathrm{cm})$

5) Stem elongation rate (SER), which is the summation of all the stem/pseudo-stem elongations per tiller divided by the number of days of the evaluation period ( $\mathrm{cm} /$ tiller.day) and

6) Accumulation of stem per tiller, which is calculated from the difference between the height of the ligule of the last expanded leaf on the last evaluation day and the height of the ligule of the first leaf tagged at the beginning of the evaluation $(\mathrm{cm})$. 
The variables were grouped by season (winter, spring, summer and autumn) due to the varying nature of the intervals and the number of grazing cycles in the evaluated treatments. The data were submitted to the analysis of variance, utilizing the GLM procedure of the SAS statistical package (SAS Institute, 1993). It was used a split-plot arrangement in which the treatments (Res/LI) constituted the plots and the season constituted the subplots. The RANDOM and TEST commands were used for identification and performing the suitable tests. The levels of LI were regarded as the discrete variable because of the small amount of levels evaluated. The comparison of means was performed by appropriate contrasts for the main effects, the effects of residue (RES), the effects of LI and for the nested effects of RES (LI) and LI(RES), using Tukey's test at $10 \%$ probability.

\section{Results and Discussion}

The morphogenic and structural characteristics varied significantly among frequencies, intensities of defoliation and seasons of the year. Structural characteristics are ruled by the morphogenic characteristics (Chapman \& Lemaire, 1993).

The leaf elongation rate (LER) was affected by residue $(\mathrm{P}=0.1000)$, light interception $(\mathrm{P}=0.0005)$, residue $\times$ light interception interaction $(\mathrm{P}=0.0312)$, season $(\mathrm{P}=0.0001)$, light interception $\times$ season interactions $(\mathrm{P}=0.0001)$ and residue $\times$ light interception $\times$ season interactions $(\mathrm{P}=0.0001$; Table 1$)$.

Table 1 - Leaf elongation rate (cm/tiller.day) of guinea grass cv. Tanzania swards at various defoliation intensities and frequencies during the seasons

\begin{tabular}{|c|c|c|c|c|}
\hline \multirow[t]{2}{*}{ Residue (cm) } & \multicolumn{3}{|c|}{ Light interception (\%) } & \multirow[b]{2}{*}{ Mean } \\
\hline & 90 & 95 & 100 & \\
\hline & & Winter & & \\
\hline 25 & $0.90 \mathrm{bB}$ & $1.07 \mathrm{bA}$ & $1.14 \mathrm{bA}$ & $1.04 \mathrm{~b}$ \\
\hline 50 & $1.32 \mathrm{aA}$ & $1.24 \mathrm{aA}$ & $1.27 \mathrm{aA}$ & $1.28 \mathrm{a}$ \\
\hline \multirow[t]{2}{*}{ Mean } & $1.11 \mathrm{~A}$ & $1.16 \mathrm{~A}$ & $1.21 \mathrm{~A}$ & $1.16 \mathrm{D}^{\prime}$ \\
\hline & & Spring & & \\
\hline 25 & $3.79 b B$ & $4.92 \mathrm{aA}$ & $1.34 \mathrm{bC}$ & $3.35 b$ \\
\hline 50 & $4.21 \mathrm{aB}$ & $4.80 \mathrm{aA}$ & $2.01 \mathrm{aC}$ & $3.68 a$ \\
\hline \multirow[t]{2}{*}{ Mean } & $4.00 \mathrm{~B}$ & $4.86 \mathrm{~A}$ & $1.68 \mathrm{C}$ & $3.52 \mathrm{~B}^{\prime}$ \\
\hline & & Summer & & \\
\hline 25 & $3.74 \mathrm{aA}$ & $4.46 \mathrm{aA}$ & $4.25 \mathrm{aA}$ & $4.15 \mathrm{a}$ \\
\hline 50 & 4.13aAB & $3.68 \mathrm{bB}$ & $4.70 \mathrm{aA}$ & $4.17 \mathrm{a}$ \\
\hline \multirow[t]{2}{*}{ Mean } & $3.94 \mathrm{~B}$ & $4.07 \mathrm{AB}$ & $4.48 \mathrm{~A}$ & $4.16 \mathrm{~A}^{\prime}$ \\
\hline & & Autumn & & \\
\hline 25 & 4.19a A & $2.34 \mathrm{aB}$ & $2.68 \mathrm{bB}$ & $3.08 \mathrm{a}$ \\
\hline 50 & $2.74 \mathrm{bB}$ & $3.04 \mathrm{aAB}$ & $3.56 \mathrm{aA}$ & $3.12 \mathrm{a}$ \\
\hline Mean & $3.47 \mathrm{~A}$ & $2.67 \mathrm{~B}$ & $3.21 \mathrm{AB}$ & $3.01 C^{\prime}$ \\
\hline
\end{tabular}

Means with the same lower case letter in the column and capital letter in the row within season of the year do not significantly differ from each other $(\mathrm{P}>0.10)$ by Tukey's test.

Means followed by capital letter followed by (') compare seasons of the year ( $\mathrm{P}>0.10)$ by Tukey's test.
The LER was thehighest during summer(4.16 cm/tiller/day) and the lowest in the winter $(1.16 \mathrm{~cm} /$ tiller.day). These results can be explained by the greater availability of growth factors such as water, temperature and light during the summer. According to Ludlow \& Ng (1977), leaf expansion is one of the physiological processes most sensitive to water deficit. This is because division and cell growth are extremely sensitive to cell turgor, causing leaf and root elongation to be interrupted long before the processes of photosynthesis and cell division are affected (Ludlow \& Ng, 1977).

Leaf appearance rate (LAR) was influenced by several factors including residue ( $\mathrm{P}=0.0162)$, light interception $(\mathrm{P}=0.0001)$, season $(\mathrm{P}=0.0001)$, residue $\times$ light interception interactions $(\mathrm{P}=0.0710)$, residue $\times$ season interactions $(\mathrm{P}=0.0019)$, light interception $\times$ season interactions $(\mathrm{P}=0.0001)$ and residue $\times$ light interception $\times$ season interactions $(\mathrm{P}=0.0006)$. Similar to LER, LAR was the highest during the summer (0.09 leaf/tiller.day) and lowest during the winter ( 0.04 leaf/tiller.day). This can be explained by differences in the availability of the growth factors during the different seasons (Table 2).

The effects of residue and light interception differed significantly between the seasons. Grazing intervals with high defoliation intensities caused an increase in LAR. According to Nabinger (1997) and Bos \& Neutboon (1998), environmental factors such as light and temperature can

Table 2 - Leaf appearance rate (leaf/tiller.day) of guinea grass cv. Tanzania swards at various defoliation intensities and frequencies during the seasons

\begin{tabular}{cllll}
\hline Residue $(\mathrm{cm})$ & \multicolumn{3}{c}{ Light interception (\%) } \\
\cline { 2 - 3 } & \multicolumn{1}{c}{90} & \multicolumn{1}{c}{95} & \multicolumn{1}{c}{100} & Mean \\
\hline & & Winter & \\
25 & $0.037 \mathrm{bB}$ & $0.042 \mathrm{aA}$ & $0.040 \mathrm{aAB}$ & $0.040 \mathrm{a}$ \\
50 & $0.041 \mathrm{aA}$ & $0.039 \mathrm{bA}$ & $0.040 \mathrm{aA}$ & $0.040 \mathrm{a}$ \\
Mean & $0.039 \mathrm{~A}$ & $0.040 \mathrm{~A}$ & $0.040 \mathrm{~A}$ & $0.040 \mathrm{C}$ \\
& & Spring & & \\
25 & $0.090 \mathrm{aB}$ & $0.111 \mathrm{aA}$ & $0.032 \mathrm{bC}$ & $0.078 \mathrm{a}$ \\
50 & $0.092 \mathrm{a} A$ & $0.097 \mathrm{bA}$ & $0.049 \mathrm{aB}$ & $0.079 \mathrm{a}$ \\
Mean & $0.091 \mathrm{~B}$ & $0.104 \mathrm{~A}$ & $0.040 \mathrm{C}$ & $0.078 \mathrm{~B}$ \\
& & & & \\
25 & $0.094 \mathrm{aB}$ & $0.093 \mathrm{aB}$ & $0.107 \mathrm{aA}$ & $0.098 \mathrm{a}$ \\
50 & $0.087 \mathrm{a}$ & $0.077 \mathrm{bA}$ & $0.084 \mathrm{bA}$ & $0.083 \mathrm{~b}$ \\
Mean & $0.090 \mathrm{AB}$ & $0.085 \mathrm{~B}$ & $0.096 \mathrm{~A}$ & $0.090 \mathrm{~A}$ \\
& & & & \\
25 & $0.108 \mathrm{aA}$ & $0.072 \mathrm{aB}$ & $0.064 \mathrm{aB}$ & $0.081 \mathrm{a}$ \\
50 & $0.086 \mathrm{bA}$ & $0.066 \mathrm{aB}$ & $0.075 \mathrm{aAB}$ & $0.076 \mathrm{a}$ \\
Mean & $0.097 \mathrm{~A}$ & $0.068 \mathrm{~B}$ & $0.069 \mathrm{~B}$ & $0.078 \mathrm{~B}$ \\
\hline
\end{tabular}

Means with the same lower case letter in the column and capital letter in the row within season of the year do not significantly differ from each other $(P>0.10)$ by Tukey's test.

Means followed by capital letter followed by (') compare seasons of the year $(\mathrm{P}>0.10)$ by Tukey's test. 
influence LAR. These factors are related to the upper part of the canopy being shaded by leaves and other structures, inhibiting the activity of buds and endangering the formation of new leaves and new tillers (Frank \& Hofman, 1994). More frequent defoliations enabled greater removal of leaf tissues and, as a result, increased leaf production. The increased leaf production was probably caused by the greater light penetration at the canopy base.

The behavior of phyllochron was similar to the behavior of LAR. The phyllochron was affected by light interception $(\mathrm{P}=0.0001)$, season $(\mathrm{P}=0.0001)$, residue $\times$ interception interactions $(\mathrm{P}=0.0022)$, season $\times$ residue interactions $(\mathrm{P}=0.0013)$, season $\times$ light interception interactions $(\mathrm{P}=0.0001)$ and residue $\times$ light interception $\times$ season interactions $(\mathrm{P}=0.0001)$. The highest value of phyllochron was recorded during the winter (27 days), and the lowest was recorded during the summer (12 days). Intermediate values were recorded during the spring and autumn.

The final length of the leaf blade (FLLB) was affected by the residue $(\mathrm{P}=0.0001)$, light interception $(\mathrm{P}=0.0002)$, season $(\mathrm{P}=0.0001)$, residue $\times$ light interception interactions $(\mathrm{P}=0.0121)$, light interception $\times$ season interactions $(\mathrm{P}=0.0033)$ and residue $\times$ light interception $\times$ season interactions $(\mathrm{P}=0.0001)$. The highest values of leaf blade length were recorded during the spring $(48.2 \mathrm{~cm})$ and summer $(48.9 \mathrm{~cm})$. These results can be explained by the more favorable climate conditions for the growth of tillers during these seasons. The lowest value was recorded during the winter $(32.5 \mathrm{~cm})$. The paddocks highest values of final length of leaf blade were observed in the paddocks with a residue of $50 \mathrm{~cm}$ (36.6 cm to $52.6 \mathrm{~cm}$; Table 3).

The lower values of FLLB for the paddocks with a $25 \mathrm{~cm}$ residue were not affected by the season and ranged from $28.4 \mathrm{~cm}$ to $46.7 \mathrm{~cm}$. Furthermore, the paddocks with the paddocks with the highest defoliation intensity yielded shorter length of the leaf sheath. This could have been caused by a reduction of the cell multiplication phase, leading to a shorter final length of the blade, as demonstrated by Duru \& Ducrocq (2000). According to Lemaire \& Chapman (1996), the length of the leaf blade is a plastic characteristic responsive to defoliation severity and it is regarded as a morphologic strategy of the plant to escape grazing.

The $90 \%$ frequency of LI resulted in shorter lengths of leaf blades during each season with the exception of winter, when no differences were detected. This was probably a result of the high LAR. Furthermore, the shortest length of the sheath for the $95 \%$ and $100 \%$ frequencies of LI resulted in lower values of final lengths of leaf blades. This might have been caused by the poor accumulation of stems on the tiller (Barbosa et al., 2007).
Table 3 - Final length of leaf blade $(\mathrm{cm})$ of guinea grass cv. Tanzania swards at various defoliation intensities and frequencies during the seasons

\begin{tabular}{|c|c|c|c|c|}
\hline \multirow[t]{2}{*}{$\overline{\text { Residue }(\mathrm{cm})}$} & \multicolumn{3}{|c|}{ Light interception (\%) } & \multirow[b]{2}{*}{ Mean } \\
\hline & 90 & 95 & 100 & \\
\hline & & Winter & & \\
\hline 25 & $26.80 \mathrm{bA}$ & $29.10 \mathrm{bA}$ & $29.30 \mathrm{bA}$ & $28.40 \mathrm{~b}$ \\
\hline 50 & $38.10 \mathrm{aA}$ & $35.60 \mathrm{aA}$ & $36.10 \mathrm{aA}$ & $36.60 \mathrm{a}$ \\
\hline \multirow[t]{2}{*}{ Mean } & $32.40 \mathrm{~A}$ & $32.30 \mathrm{~A}$ & $32.70 \mathrm{~A}$ & $32.50 C^{\prime}$ \\
\hline & & Spring & & \\
\hline 25 & $42.00 \mathrm{aB}$ & $49.50 \mathrm{aA}$ & $40.20 \mathrm{bB}$ & $43.90 \mathrm{~b}$ \\
\hline 50 & $46.00 \mathrm{aC}$ & $53.00 \mathrm{aB}$ & $58.80 \mathrm{aA}$ & $52.60 \mathrm{a}$ \\
\hline \multirow[t]{2}{*}{ Mean } & $44.00 \mathrm{~B}$ & $51.20 \mathrm{~A}$ & $49.50 \mathrm{~A}$ & $48.20 \mathrm{~A}$ \\
\hline & & Summer & & \\
\hline 25 & $40.80 \mathrm{bB}$ & $47.90 \mathrm{aA}$ & $51.90 \mathrm{bA}$ & $46.70 \mathrm{~b}$ \\
\hline 50 & $46.90 \mathrm{aB}$ & $48.70 \mathrm{aB}$ & $57.30 \mathrm{aA}$ & $50.90 a$ \\
\hline \multirow[t]{2}{*}{ Mean } & $43.80 \mathrm{C}$ & $48.30 \mathrm{~B}$ & $54.60 \mathrm{~A}$ & $48.90 \mathrm{~A}$ \\
\hline & & Autumn & & \\
\hline 25 & $38.80 \mathrm{aA}$ & $34.50 \mathrm{bB}$ & $36.90 \mathrm{bAB}$ & $36.80 \mathrm{~b}$ \\
\hline 50 & $35.70 \mathrm{aB}$ & $48.20 \mathrm{aA}$ & $48.60 \mathrm{aA}$ & $44.20 \mathrm{a}$ \\
\hline Mean & $37.30 \mathrm{~B}$ & $41.40 \mathrm{~A}$ & $42.80 \mathrm{~A}$ & $40.50 B^{\prime}$ \\
\hline
\end{tabular}

Means with the same lower case letter in the column and capital letter in the row within the season of the year do not significantly differ from each other $(\mathrm{P}>0.10)$ by Tukey's test.

Means followed of capital letter followed by (') compare seasons of the year $(\mathrm{P}>0.10)$ by Tukey's test.

The results for the final length of leaf blades were similar to the results for the LER. There was a positive correlation between the increases in the LER and FLLB. During the winter and spring, the highest values of the LER for the $50-\mathrm{cm}$ residues were $1.28 \mathrm{~cm} /$ tiller.day and $3.68 \mathrm{~cm} /$ tiller.day, respectively. This caused the final length of leaf blades to increase. The highest LER in the same paddocks were observed during the times of low temperatures and precipitation. These results can be explained by the larger mass of residue forage, which may have provided greater nitrogen mobilization from older leaves to the younger leaves (Nabinger \& Pontes, 2001).

The population density of tillers was influenced by light interception $(\mathrm{P}=0.0002)$, season $(\mathrm{P}=0.0001)$, residue $\times$ season interactions $(\mathrm{P}=0.0320)$ and residue $\times$ light interception $\times$ season interactions (Table 4 ).

The morphogenic characteristic determining the population density of tillers is the leaf appearance rate (LAR) (Davies, 1974; Mazzanti et al., 1994). However, even with the high LAR during the summer, the paddock population density of tillers remained smaller in the paddocks with $100 \%$ LI compared to the paddocks with $90 \%$ and $95 \% \mathrm{LI}$.

The reason for the differences in the population density of tillers was the light interception. The lowest population densities were found in the paddocks with $100 \% \mathrm{LI}$, and they were between 324 tillers $/ \mathrm{m}^{2}$ and 524 tillers $/ \mathrm{m}^{2}$. This can 
Table 4 - Population density of tillers (tillers $/ \mathrm{m}^{2}$ ) of guinea grass cv. Tanzania swards at various defoliation intensities and frequencies during the seasons

\begin{tabular}{ccccc}
\hline Residue $(\mathrm{cm})$ & \multicolumn{3}{c}{ Light } & \\
\cline { 2 - 3 } & 90 & 95 & 100 & Mean \\
\cline { 2 - 3 } 25 & $475 \mathrm{aA}$ & Winter & \\
50 & $470 \mathrm{aA}$ & $470 \mathrm{aA}$ & $366 \mathrm{aB}$ & $435 \mathrm{a}$ \\
Mean & $472 \mathrm{~A}$ & $405 \mathrm{~B}$ & $345 \mathrm{C}$ & $407 \mathrm{D}$ \\
& & & & \\
& & Spring & & \\
25 & $643 \mathrm{a}$ & $477 \mathrm{aB}$ & $390 \mathrm{aC}$ & $503 \mathrm{a}$ \\
50 & $526 \mathrm{bA}$ & $528 \mathrm{aA}$ & $389 \mathrm{aB}$ & $481 \mathrm{a}$ \\
Mean & $585 \mathrm{~A}$ & $502 \mathrm{~B}$ & $389 \mathrm{C}$ & $492 \mathrm{C}$ \\
& & & & \\
25 & $744 \mathrm{aA}$ & $654 \mathrm{aB}$ & $498 \mathrm{aC}$ & $632 \mathrm{a}$ \\
50 & $693 \mathrm{aA}$ & $614 \mathrm{aB}$ & $524 \mathrm{aC}$ & $610 \mathrm{a}$ \\
Mean & $718 \mathrm{~A}$ & $634 \mathrm{~B}$ & $511 \mathrm{C}$ & $621 \mathrm{~A}$ \\
& & Autumn & \\
25 & $631 \mathrm{aA}$ & $603 \mathrm{aAB}$ & $506 \mathrm{aB}$ & $580 \mathrm{a}$ \\
50 & $662 \mathrm{aA}$ & $591 \mathrm{aA}$ & $462 \mathrm{aB}$ & $572 \mathrm{a}$ \\
Mean & $647 \mathrm{~A}$ & $597 \mathrm{~A}$ & $484 \mathrm{~B}$ & $576 \mathrm{~B}$ \\
\hline
\end{tabular}

Means with the same lower case letter in the column and capital letter in the row within season of the year do not significantly differ from each other $(\mathrm{P}>0.10)$ by Tukey's test.

Means followed by capital letter followed by (') compare seasons of the year $(\mathrm{P}>0.10)$ by Tukey's test.

be explained by the processes of intra-species competition by growth factors such as light. This gives rise to a process known as "compensation size/population density of tillers" (Matthew et al., 1995). Thus, when rotational stocking is used, the regrowth of the grazing land starts with an increased number of larger tillers. This process begins soon after grazing. During the $95 \%$ interception of incident light, both the quantity and quality of light is limited. As a result, tillering is reduced, and the death of tillers begins to occur. Increases in the size of the tillers compensate for reductions in the number of tillers. Furthermore, during situations of intense competition for light such as $100 \%$ LI, the composition of the light spectrum in the interior canopy changes, reducing to blue light and of the ratio red light: infrared light (Gautier et al., 1999). This alteration in the light spectrum reduces the tillering and the population density of tillers.

According to Davies et al. (1983), plants submitted to shading prioritize the allocation of assimilates to the growth of existing tillers to the detriment of the formation of new tillers. Thus, the young tillers would die first as a result of the overlapping and shading by the older tillers (Ong et al., 1978). Furthermore, some buds are probably aborted even before the emergence of new tillers in shaded grazing lands (Sbrissia \& Da Silva, 2001). Barbosa et al. (2002) demonstrated that in Tanzania grass under rotational stocking, the number of basilar and aerial tillers decreased linearly during the regrowth period. However, the LAI increased.

In general, the treatments of 90\% LI resulted in a high population density of tillers, varying from 470 tillers $/ \mathrm{m}^{2}$ to 744 tillers $/ \mathrm{m}^{2}$. This was promoted by high LAR and by the decreased effect of shading which is inherent to the plant community at the end of the regrowth period (Korte, 1986). However, those tillers were smaller in size. This was most evident for the $25 \mathrm{~cm}$ residue, which was also where the lowest values of FLLB were observed. According to Sbrissia \& Da Silva (2001), the population density of tillers is the component of the LAI which allows increased flexibility of the plant and different regimes of defoliation. Furthermore, LAI can be optimized in grazing lands by means of a high population density of small tillers. However, this does not necessarily mean that the population is stable as grazing lands can be kept stable even with low values of population density of tillers (Sbrissia et al., 2010).

Higher values of population density of tillers were recorded during the summer (621tillers $/ \mathrm{m}^{2}$ ), followed by the autumn, spring and winter ( 407 tillers $/ \mathrm{m}^{2}$ ). This behavior reflects the behavior observed for LAR. Furthermore, under normal conditions, seasonal fluctuations in the amount of light energy received by the plants caused seasonal variations in the leaf area and, consequently, seasonal alterations in the population density of tillers (Matthew et al., 1999). High population densities during the summer were also observed by Carnevalli et al. (2006) for guinea grass cv. Mombaça in a similar experiment. The authors attributed these results to the intense tiller renewal during that season. The effect of residue on the population density of tillers was only verified during the winter. During this season, the greatest population density was recorded for the $50 \mathrm{~cm}$ residue treatment (435 tillers $/ \mathrm{m}^{2}$ ).

The stem elongation rate (SER) was affected by residue $(\mathrm{P}=0.0691)$, light interception $(\mathrm{P}=0.0008)$, season $(\mathrm{P}=0.0001)$, residue $\times$ season interactions $(\mathrm{P}=0.0186)$, light interception $\times$ season interactions $(\mathrm{P}=0.0001)$ and residue $\times$ light interception $\times$ season interactions $(\mathrm{P}=0.0988$; Table 5$)$.

Values of SER observed during the autumn flowering time were $0.335 \mathrm{~cm} /$ tiller.day. During the winter, there were no differences in SER among the defoliation intensities. During the summer and spring, values of SER recorded for the area subjected to $100 \%$ LI were 0.125 and $0.576 \mathrm{~cm} /$ tiller.day, respectively. These values were higher than the SER values of the areas receiving 90\% and 95\% LI. During the autumn, SER was larger for the areas with residue of $25 \mathrm{~cm}(0.419 \mathrm{~cm} /$ tiller.day $)$, and the largest SER values were observed in the pre-grazing condition of $100 \%$ LI. 
Table 5 - Stem elongation rate (cm/tiller.day) of guinea grass cv. Tanzania swards at various defoliation intensities and frequencies during the seasons

\begin{tabular}{|c|c|c|c|c|}
\hline \multirow[t]{2}{*}{ Residue $(\mathrm{cm})$} & \multicolumn{3}{|c|}{ Light interception (\%) } & \multirow[b]{2}{*}{ Mean } \\
\hline & 90 & 95 & 100 & \\
\hline & & Winter & & \\
\hline 25 & $0.001 \mathrm{aA}$ & $0.011 \mathrm{aA}$ & $0.006 \mathrm{aA}$ & $0.006 \mathrm{a}$ \\
\hline 50 & $0.010 \mathrm{aA}$ & $0.005 \mathrm{aA}$ & $0.008 \mathrm{aA}$ & $0.008 \mathrm{a}$ \\
\hline \multirow[t]{2}{*}{ Mean } & $0.006 \mathrm{~A}$ & $0.008 \mathrm{~A}$ & $0.007 \mathrm{~A}$ & $0.007 C^{\prime}$ \\
\hline & & Spring & & \\
\hline 25 & $0.026 \mathrm{aB}$ & $0.099 \mathrm{aA}$ & $0.045 \mathrm{aB}$ & $0.057 a$ \\
\hline 50 & $0.028 a B$ & $0.061 \mathrm{aAB}$ & $0.084 \mathrm{aA}$ & $0.058 a$ \\
\hline \multirow[t]{2}{*}{ Mean } & $0.027 \mathrm{~B}$ & $0.080 \mathrm{~A}$ & $0.065 \mathrm{~A}$ & $0.057 \mathrm{BC}$ \\
\hline & & Summer & & \\
\hline 25 & $0.049 \mathrm{aB}$ & $0.042 \mathrm{aB}$ & $0.127 \mathrm{aA}$ & $0.076 a$ \\
\hline 50 & $0.071 \mathrm{aB}$ & $0.060 \mathrm{aB}$ & $0.124 \mathrm{aA}$ & $0.085 a$ \\
\hline \multirow[t]{2}{*}{ Mean } & $0.065 \mathrm{~B}$ & $0.051 \mathrm{~B}$ & $0.125 \mathrm{~A}$ & 0.080B \\
\hline & & Autumn & & \\
\hline 25 & $0.155 \mathrm{aB}$ & $0.348 \mathrm{aB}$ & $0.756 \mathrm{aA}$ & $0.419 a$ \\
\hline 50 & $0.207 \mathrm{aA}$ & $0.149 \mathrm{a} A$ & $0.395 \mathrm{bA}$ & $0.250 \mathrm{~b}$ \\
\hline Mean & $0.181 \mathrm{~B}$ & $0.247 B$ & $0.576 \mathrm{~A}$ & $0.335 \mathrm{~A}^{\prime}$ \\
\hline
\end{tabular}

Means with the same lower case letter in the column and capital letter in the row within the season of the year do not significantly differ from each other $(\mathrm{P}>0.10)$ by Tukey's test.

Means followed by capital letter followed by (') compare seasons of the year $(\mathrm{P}>0.10)$ by Tukey's test.

The stem accumulation in the tiller was affected by light interception $(\mathrm{P}=0.0001)$, season $(\mathrm{P}=0.0001)$ and light interception $\times$ season interactions $(\mathrm{P}=0.0001)$. The accumulation of stems in the tiller did not differ between the residues of $25 \mathrm{~cm}$ and $50 \mathrm{~cm}$. However, there were significant differences between the levels of light interception and the seasons (Table 6).

The greatest accumulation of stems per tiller was recorded in autumn. Stem accumulation on the tiller increased as the levels of light interception were raised from $90 \%$ to $100 \%$ in every season except for winter. During the winter, there was no correlation between stem accumulation and the level of light interception. The areas with $100 \%$ light interception had the highest stem elongation, which was mainly observed during the summer and autumn. The stem is an important morphological component of grass. It has supported functions in the

Table 6 - Stem accumulation (cm/tiller) of guinea grass cv. Tanzania swards at three levels of light interception

\begin{tabular}{lcccc}
\hline Season & \multicolumn{3}{c}{ Light } & \multirow{2}{*}{ Mean } \\
\cline { 2 - 3 } & 90 & 95 & 100 & \\
\hline Winter & $0.4 \mathrm{a}$ & $0.5 \mathrm{a}$ & $0.5 \mathrm{a}$ & $0.5 \mathrm{C}$ \\
Spring & $0.8 \mathrm{c}$ & $2.2 \mathrm{~b}$ & $4.3 \mathrm{a}$ & $2.4 \mathrm{BC}$ \\
Summer & $1.9 \mathrm{~b}$ & $1.7 \mathrm{~b}$ & $5.7 \mathrm{a}$ & $3.1 \mathrm{~B}$ \\
Autumn & $6.0 \mathrm{~b}$ & $12.8 \mathrm{~b}$ & $25.5 \mathrm{a}$ & $14.8 \mathrm{~A}$ \\
\hline
\end{tabular}

Means with the same small letter in the row and capital letter in the column do not significantly differ from each other $(\mathrm{P}>0.10)$ by Tukey's test. spatial arrangement of the plant and assimilates translocation to the leaves (Fagundes et al., 2006). The accumulation of stems increased during the spring as the water deficit decreased. During the autumn flowering, stem accumulation on the tiller became more noticeable as a consequence of the high SER. The highest stem accumulation was recorded during the combination of $25 \mathrm{~cm}$ of post-grazing residue and $100 \%$ of light interception at pre-grazing. During the autumn, the accumulation of stems in the areas with $100 \%$ LI was 4.25 times larger than in the areas with 90\% LI and 2.0 times larger than in the areas with 95\% LI. These results indicate that long periods of rest during the autumn can endanger the canopy structure.

\section{Conclusions}

Defoliation frequency is a determining factor in the expression of phenotypic plasticity. This is mainly caused by variations in the population density of tillers, which affects the control of stem elongation.

\section{References}

BARBOSA, R.A.; NASCIMENTO JÚNIOR, D.; EUCLIDES, V.P.B. et al. Características morfogênicas e acúmulo de forragem do capim-tanzânia (Panicum maximum Jacq. cv. Tanzânia) em dois resíduos forrageiros pós-pastejo. Revista Brasileira de Zootecnia, v.31, n.2, p.583-593, 2002.

BARBOSA, R.A.; NASCIMENTO JÚNIOR, D.; EUCLIDES, V.P.B. et al. Capim-tanzânia submetido a combinações entre intensidade e freqüência de pastejo. Pesquisa Agropecuária Brasileira, v.42, n.3, p329-340, 2007.

BOS, H.J.; NEUTEBOON, J.H. Morphological analysis of leaf and tiller number dynamics of wheat (Triticum aestivum L.): responses to temperature and light intensity. Annals of Botany, v.81, p.131-139, 1998.

CAETANO, L.P.S.; DIAS-FILHO, M.B. Responses of six Brachiaria spp. accessions to root zone flooding.Revista Brasileira de Zootecnia, v.37, n.5, p.795-801, 2008.

CARNEVALLI, R.A.; DA SILVA, S.C.; BUENO, A.A.O. et al.Herbage production and grazing losses in Panicum maximum cv. Mombaça under four grazing managements. Tropical Grasslands, v.40, p.165-176, 2006.

CHAPMAN, D.F.; LEMAIRE, G. Morphogenetic and structural determinants of plant regrowth after defoliation. In: BAKER, M.J. (Ed.). In: Grasslands for our world. Wellington: SIR Publishing, 1993. p.55-64.

DAVIES, A. Leaf tissue remaining after cutting and regrowth in perennial ryegrass. Journal Agriculture Science, v.82, p165-172, 1974.

DAVIES, A.; EVANS, M.E.; EXLEY, J.K. Regrowth of perennial ryegrass as affected by simulated leaf sheaths. Journal of Agricultural Science, v.101, p.131-137, 1983.

DIFANTE, G.S; NASCIMENTO JÚNIOR, D.; DA SILVA, S.C. et al. Dinâmica do perfilhamento do capim-marandu cultivado em duas alturas e três intervalos de corte. Revista Brasileira de Zootecnia, v.37, n.2, p.189-196, 2008.

DIFANTE, G.S.; NASCIMENTO JÚNIOR, D.; EUCLIDES, V.P.B. et al. Sward structure and nutritive value of Tanzânia guinea grass subjected to rotational stocking managements. Revista Brasileira de Zootecnia, v.38, n.1, p.9-19, 2009. 
DURU, M.; DUCROCQ, H. Growth and senescence of the successive grass leaves on a tiller. Ontogenic development and effect of temperature. Annals of Botany, v.85, p.635-643, 2000.

EUCLIDES, V.P.B.; CARDOSO, E.G.; MACEDO, M.C.M. et al. Consumo voluntário de Brachiaria decumbens cv. Basilisk e Brachiaria brizantha cv. Marandu sob pastejo. Revista Brasileira de Zootecnia, v.29, n.6, p.2200-2208, 2000 (supl. 2).

FAGUNDES, J.L.; FONSECA, D.M.; MISTURA, C. et al. Características morfogênicas e estruturais do capim-braquiária em pastagem adubada com nitrogênio avaliadas nas quatro estações do ano. Revista Brasileira de Zootecnia, v.35, n.1, p.21-29, 2006.

FOOD AND AGRICULTURE ORGANIZATION - FAO. World reference base for soil resources 2006: a framework for international classification, correlation and communication. Rome: FAO, 2006. 145p. (World Soil Resources Report, 103).

FRANK, A.B.; HOFMAN, L. Light quality and stem numbers in cool-season forage grasses. Crop Science, v.34, n.2, p.468-473, 1994.

GARCEZ NETO, A.F.; NASCIMENTO JÚNIOR, D.; REGAZZI, A.J. et al.Respostas morfogênicas e estruturais de Panicum maximum cv. Mombaça sob diferentes níveis de adubação nitrogenada e alturas de corte. Revista Brasileira de Zootecnia, v.31, n.5, p.1890-1900, 2002.

GAUTIER, H.; VARLET-GRANCHER, C.; HAZARD, L. Tillering responses to the light environment and to defoliation in populations of perennial ryegrass (Lolium perene L.) selected for contrasting leaf length. Annals of Botany, v.83, p.423-429, 1999.

HODGSON, J. Grazing management: science into practice. New York: John Wiley \& Sons, 1990. 203p.

KORTE, C.J. Tillering in “Grasslands Nui” perennial ryegrass swards. 2. Seasonal pattern of tillering and age of flowering tillers with two mowing frequencies. New Zealand Journal of Agricultural Research, v.29, p.629-638, 1986.

LEMAIRE, G.; CHAPMAN, D. Tissue flows in grazed plant communities. In: HODGSON, J.; ILLIUS, A.W. (Eds.) The ecology and management of grazing systems. Wallingford: Cab International, 1996. p.3-36.

LUDLOW, M.M.; NG, T.T. Leaf elongation rate in Panicum maximum var. trichoglume following removal of water stress. Australian Journal of Plant Physiology, v.42, p.263-272, 1977.
MATTHEW, C.; LEMAIRE, G.; SACKVILLE-HAMILTON, N.R. et al. A modified self-thinning equation to describe to size/ density relationships for defoliated swards. Annals of Botany, v.76, p.579-587, 1995.

MATTHEWS, P.N.P.; HARRINGTON, K.C.; HAMPTON, J.G. Management of grazing systems. In: WHITE, J.; HODGSON, J. (Eds.) In: New Zealand pasture and crop science. Auckland: Oxford University Press, 1999. p.153-174.

MAZZANTI, A.; LEMAIRE,G.; GASTAL, F. The effect of nitrogen fertilization on the herbage production of tall fescue swards grazed continuously with sheep. 1 - Herbage growth dynamics. Grass and Forage Science, v.49, p.111-120, 1994.

NABINGER, C. Eficiência do uso de pastagens: disponibilidade e perdas de forragem. In: SIMPÓSIO SOBRE MANEJO DA PASTAGEM, 14., 1997, Piracicaba. Anais... Piracicaba: Fundação de Estudos Agrários “Luiz de Queiroz”, 1997. p.231-251.

NABINGER, C.; PONTES, L.S. Morfogênese de plantas forrageiras e estrutura do pasto. In: REUNIÃO ANUAL DA SOCIDADE BRASILEIRA DE ZOOTECNIA, 38., 2001, Piracicaba. Anais... Piracicaba: SBZ, 2001. p.755-771.

ONG, C.K.; MARSHALL, C.; SAGAR, G.R. The physiology of tiller death in grasses. 2. Causes of tiller death in grass swards. Journal of the British Grassland Society, v.17, p.205-211, 1978.

SANTOS, P.M.; BALSALOBRE, M.A.; CORSI, M. Características morfogenéticas e taxa de acúmulo de forragem do capimmombaça submetido a três intervalos de corte. Revista Brasileira de Zootecnia, v.33, n.4, p.843-851, 2004.

STATISTICAL ANALYSES SYSTEM - SAS. SAS/STAT - user's guide statistics, versão 6, 4. ed. Cary: 1993. v.1,2.

SRISSIA, A.F.; DA SILVA, S.C.; SARMENTO, D.O.L. et al.Tillering dynamics in palisadegrass swards continuously stocked by cattle. Plant Ecology, v.206, p.349-359, 2010.

SBRISSIA, A.F.; DA SILVA, S.C. O ecossistema de pastagens e a produção animal In: REUNIÃO ANUAL DA SOCIDADE BRASILEIRA DE ZOOTECNIA, 38., 2001, Piracicaba. Anais... Piracicaba: SBZ, 2001. p.731-754.

VAN ESBROECK, G.A.; KING, J.R.; BARON, V.S. Effects of temperature and photoperiod on the extension growth of six temperate grasses. In: INTERNATIONAL GRASSLAND CONGRESS, 16., 1989, Nice. Proceedings... Nice, s.ed., 1989. p.459-4460. 